\title{
THE OCCURENCE OF RARE AND PROTECTED PLANT SPECIES ON THE PEAT BOG NEAR LAKE BIKCZE (LĘCZYŃSKO-WLODAWSKIE LAKELAND)
}

\author{
Magdalena Pogorzelec, Barbara Banach
}

\author{
Department of General Ecology, University of Life Sciences, Akademicka 13, 20-950 Lublin, Poland \\ e-mail: m.pogorzelec@op.pl; barbara.banach@up.lublin.pl
}

Received: 11.09.2008

S u m m a r y

This paper presents the results of a pilot field study, conducted in July 2007, designed to make floristic evaluation of the peat bog area adjacent to the western shore of Lake Bikcze (Łęczyńsko-Włodawskie Lakeland). The main aim of the study was to confirm the occurrence of populations of rare and legally protected plant species in this area and to identify, on a preliminary basis, habitat conditions in their stands.

The occurrence of populations of the following strictly protected plant species: Betula humilis, Salix lapponum, Salix myrtilloides, Carex limosa, Drosera intermedia, Drosera rotundifolia, Dactylorhiza incarnata; and partially protected species: Menyanthes trifoliata, has been confirmed in the studied peat bog.

Both an investigation of abiotic factors, conducted in situ, and an analysis of the species composition of the flora in terms of habitat preferences of particular groups of taxa have shown that the described rare plant species find suitable conditions for their growth and development in the studied peat bog.

Key words: protected species, habitat conditions, peat bog, Lake Bikcze

\section{INTRODUCTION}

Lake Bikcze is situated in the south-eastern part of Łęczyńsko-Włodawskie Lakeland. In the past, it was a flow-through lake, fed and drained by the Piwonia River. Currently, it is largely surrounded by a drainage ditch and an embankment.

According to R a d w an (2003), the existence of wetland areas in the environs of Lake Bikcze was noted already at the beginning of the 19th century. But the first references in literature on the vegetation cover of this area appeared in 1953. On its east side, the lake had a sandy shore, whereas on the other sides it was surrounded by a belt of fens and transitional bogs with a width of about 200-250 m, with numerous peat pits (located on the western and northern shores, W i l g a t
1953). In the ground cover of the shoreface, there was noted the occurrence of the Caricetum diandrae and Caricetum elatae associations, with a large share of Equisetum fluviatile and Thelypteris palustris, as well as, at a distance of over a dozen meters from the shore, a dominance of the Molinietum medioeuropaeum association with a share of willow and alder thickets (Fijałk owski, 1959).

During the works associated with the construction of the Wieprz-Krzna Canal, Lake Bikcze was completely diked off and converted into a retention reservoir. The drainage ditch was constructed in order to stop pollutants running off the neighbouring fields. It was designed to mainly protect the peat bogs located beyond the ditch as well as Lake Bikcze itself. Only several years after the improvements, a transformation of fertile fens of the lake environs into transitional bogs was observed, and then the transitional bogs were transformed into raised bogs. Thus, the above described drainage operations probably determined the correct functioning of the peat bogs surrounding Lake Bikcze (W o j c i e c h ow s ki, 1979).

Currently, the space between the water table of the reservoir and the embankment body is covered by a transitional bog. A part of the peat bog, in particular from the western and northern side, undergoes strong biocenotic succession. The intensive development of the communities with grey willow and the encroachment of species such as silver birch or common reed have a significant impact on the change of habitat conditions in this area (primarily, aquatic and light conditions), which determine the withdrawal of species characteristic for the bog flora. The preserved parts of the peat bog are currently a habitat for many species of the relict flora, among others, Carex limosa, Eriophorum angustifolium, Drosera rotundifolia, Epipactis palustris, Dactylorhiza incarnata, Batula humilis, Salix myrtilloides, Salix lapponum and Menyanthes trifoliata or Andromeda polifolia (B a ryła 
and Fijałkowski, 1995; Lorens et al. 1998; Pogorzelec, 2004; B olek, 2005; Burzak, 2005).

The bog flora on Lake Bikcze undergoes continuous transformations as a result of changing habitat conditions there. In spite of these ongoing transformations, this area has very precious natural values and requires interest from scientists and nature conservation services.

This paper presents the results of a pilot field study, conducted in July 2007, designed to make floristic evaluation of the peat bog area. The main aim of the study was to confirm the occurrence of populations of rare and legally protected plant species in this area (in accordance with the Regulation of the Minister of Environment of 9 July 2004, Dz. U. (Journal of Laws) No. 168) and to identify, on a preliminary basis, habitat conditions in their stands.

\section{MATERIALS AND METHODS}

The field study was carried out in July 2007 in the peat bog adjacent to Lake Bikcze. The first stage of the study involved the penetration of the area on foot in order to identify the location of rare and legally protected plant species in the peat bog. Subsequently, 4 representative plots were selected, the size of which was dependent on the location and population density of the studied rare plant species in the respective bog part. The plots were described in terms of their location in the peat bog, shading and the level of the highest groundwater layer (measured in centimetres at a pressure of about $70 \mathrm{~kg}$ on the substrate surface). In situ measurements were made of the groundwater $\mathrm{pH}(\mathrm{pH}$, using a field $\mathrm{pH}$-meter) and electrolytic conductivity ( $\mu \mathrm{S} \mathrm{cm}^{-3}$; using a field conductometer).

The state of the phytocoenoses in the plots was documented by making and analysing floristic lists. Plant species were identified following R u t k o w s k i (1998). Botanical nomenclature, Latin and Polish, followed Mirek et al. 2002. Plant species present in the study areas were assigned to syntaxonomic classes (Matuszkiewicz, 2002). During office investigations, Ecological indicator values of vascular plants (Zarzycki and Korzeniak, 2002) was used to determine specific habitat conditions based on the affinity of plant species of particular phytocoenoses with characteristic ecological groups, as well as J a ccard's formula (Wysocki and Sikorski, 2002) to calculate the index of species similarity between particular phytocoenoses in which S. lapponum occurred:

$$
\mathbf{S}=\mathbf{a} / \mathbf{b}+\mathbf{c}+\mathbf{a}
$$

where: $\mathrm{S}$ - probability index; a - number of common species; $b$ - number of species present in the plot $x$ and not present in the phytocoenosis of the plot $y$; $\mathrm{c}$ - number of species present in the phytocoenosis $y$ and not present in the plot $x$. The probability index value may be within the range from 0 to 1 , where 0 means the lack of similarity between the phytocoenoses, whereas 1 means one hundred percent similarity of the species composition.

\section{RESULTS}

The preliminary exploration of the area of investigation allowed us to confirm the occurrence of populations of rare plant species in the peat bog near Lake Bikcze, that is, the following strictly protected species: Betula humilis, Salix lapponum, Salix myrtilloides, Carex limosa, Drosera intermedia, Drosera rotundifolia, Dactylorhiza incarnata; and partially protected species: Menyanthes trifoliata (Figs 1-5).

The plots were located in the central part of the peat bog (Fig. 6). They significantly varied both in terms of the species composition of their phytocoenoses (Tab. 1; Tab. 2) and selected abiotic factors of the environment (Tab. 4).

Plot I was the northernmost one; it was characterized by slight shading of the peat bog surface, a low groundwater level and the lowest $\mathrm{pH}$ of groundwater of all the studied areas ( $\mathrm{pH} 3.54)$. In its flora, the syntaxonomic classes of Phragmitetea and Alnetea glutinosae were represented in greatest numbers. Among herbaceous plants, Calla palustris, Thelypteris palustris and Peucedanum palustre were distinctly dominant species. The occurrence of over a dozen individuals of a legally protected species, Drosera intermedia, was noted.

Plot II was located in the central part of the peat bog. It was characterised by extensive shading (in particular, by tall Betula pendula individuals) and a low groundwater level. The water examined in this part of the bog was marked by the highest electrolytic conductivity of all the examined samples collected from the peat bog on Lake Bikcze $\left(433 \mu \mathrm{S} \cdot \mathrm{cm}^{-3}\right)$ and it was also distinguished by a low $\mathrm{pH}$ value (Tab. 4). The numerous occurrences of orchid Dactylorhiza incarnata were found - 19 individuals growing in a cluster and 2 Frangula alnus individuals. A total of 15 plant species, being representatives of different syntaxonomic groups, were identified in the study area (Tab. 1).

Plot III $\left(150 \mathrm{~m}^{2}\right)$ was primarily characterised by the occurrence of Salix myrtilloides in the phytocoenosis (about 200 individuals). In the flora of this stand, the numerous occurrences of Salix rosmarinifolia, Salix cinerea and Carex rostrata were noted. This study area was relatively shaded, and the groundwater level was about $10 \mathrm{~cm}$. The $\mathrm{pH}$ of the water examined in situ was 4.89 . 
Table 1

Floristic composition of plots' phytocoenoses on the peat bog near Lake Bikcze (with plant species belonging to syntaxonomic classification: Matuszkiewicz 2002).

\begin{tabular}{|c|c|c|c|c|}
\hline Plots & I & II & III & IV \\
\hline Plots area $\left(\mathrm{m}^{2}\right)$ & 100 & 220 & 150 & 880 \\
\hline Layer a density (\%) & 30 & 60 & 10 & - \\
\hline Layer b density (\%) & 40 & 50 & 30 & 20 \\
\hline Layer c coverage $(\%)$ & 50 & 50 & 60 & 70 \\
\hline Layer d coverage $(\%)$ & 70 & 20 & 50 & 60 \\
\hline Number of vascular plants & 27 & 15 & 20 & 26 \\
\hline \multicolumn{5}{|l|}{ Cl. Phragmitatea } \\
\hline Equisetum fluviatile & + & + & + & + \\
\hline Gallium palustre & + & & & + \\
\hline Calla palustris & + & & & \\
\hline Carex pseudocyperus & + & & & \\
\hline Peucedanum palustre & + & & & \\
\hline Carex vesicaria & & + & & \\
\hline Typha angustifolia & & + & + & \\
\hline Carex rostrata & & & + & \\
\hline Phragmites australis & & & + & + \\
\hline Ranunculus lingua & & & & + \\
\hline \multicolumn{5}{|c|}{ Cl. Scheuchzerio-Caricetea nigrae } \\
\hline Comarum palustre & + & + & + & + \\
\hline Menyanthes trifoliata & + & + & + & + \\
\hline Carex nigra & + & & + & + \\
\hline Viola palustris & + & & & \\
\hline Eriophorum angustifolium & & & + & + \\
\hline Carex limosa & & & & + \\
\hline Juncus articulatus & & & & + \\
\hline \multicolumn{5}{|l|}{ Cl. Oxycocco-Sphagnetea } \\
\hline Oxycoccus palustris & + & & + & + \\
\hline Eriophorum vaginatum & + & & & \\
\hline Andromeda polifolia & & & + & + \\
\hline Drosera rotundifolia & & & & + \\
\hline \multicolumn{5}{|l|}{ Cl. Alnetea glutinosae } \\
\hline Salix cinerea b & + & + & + & + \\
\hline Thelypteris palustris & + & + & + & + \\
\hline Salix pentandra $\mathrm{a} \mathrm{b}$ & + & & + & \\
\hline Calamagrostis canescens & + & & + & + \\
\hline Alnus glutinosa $\mathrm{b}$ & + & & & \\
\hline Drosera intermedia & + & & & \\
\hline Lycopus europaeus & + & & & \\
\hline Salix aurita b & + & & & \\
\hline Solanum dulcamara & + & & & \\
\hline Salix rosmarinifolia b & & + & + & + \\
\hline Frangula alnus a & & + & & \\
\hline Betula humilis b & & & & + \\
\hline \multicolumn{5}{|l|}{ Cl. Molinio-Arrhenatheretea } \\
\hline Lysimachia vulgaris & + & + & + & + \\
\hline Cirisium palustre & + & + & & \\
\hline Lythrum salicaria & + & & & + \\
\hline Galium uliginosum & & & & + \\
\hline \multicolumn{5}{|l|}{ Other species } \\
\hline Sphagnum sp. & + & + & + & + \\
\hline Betula pubescens a b & + & & & \\
\hline Poa palustris & + & & & \\
\hline Quercus petrea & + & & & \\
\hline Betula pendula $\mathrm{ab}$ & & + & + & + \\
\hline Dactylorhiza incarnata & & + & + & \\
\hline Populus tremula $\mathrm{b}$ & & + & & \\
\hline Salix myrtilloides b & & & + & \\
\hline Juncus conglomeratus & & & & + \\
\hline Salix lapponum b & & & & + \\
\hline Stellaria palustris & & & & + \\
\hline
\end{tabular}


Table 2

Jaccard similarity coefficient of species for phytocoenosis in plots (I- IV).

\begin{tabular}{cccc}
\hline Plots & II & III & IV \\
\hline I & 0.21 & 0.29 & 0.30 \\
\hline II & & 0.45 & 0.31 \\
\hline III & & & 0.51 \\
\hline
\end{tabular}

Table 3

Percentage of plant species with different habitat requirements in plots' phytocoenosis (working out on the basis of Zarzycki i Korzeniak, 2002).

\begin{tabular}{|c|c|c|c|c|c|c|c|}
\hline \multirow{2}{*}{ Selected indicators } & \multirow{2}{*}{ Plots } & \multicolumn{6}{|c|}{ Indicator values } \\
\hline & & 1 & 2 & 3 & 4 & 5 & 6 \\
\hline \multirow[t]{4}{*}{$\mathrm{L}$ - light value } & I & 0 & 3.8 & 26.9 & 80.8 & 0 & 0 \\
\hline & II & 0 & 7.1 & 21.4 & 85.7 & 7.1 & 0 \\
\hline & III & 0 & 5.3 & 10.5 & 84.2 & 10.5 & 0 \\
\hline & IV & 0 & 4.3 & 8.7 & 86.9 & 8.7 & 0 \\
\hline \multirow[t]{4}{*}{ T - temperature value } & I & 0 & 26.9 & 73.1 & 96.2 & 0 & 0 \\
\hline & II & 0 & 14.3 & 92.8 & 100 & 0 & 0 \\
\hline & III & 0 & 10.5 & 89.5 & 89.5 & 0 & 0 \\
\hline & IV & 0 & 21.7 & 86.9 & 91.3 & 0 & 0 \\
\hline \multirow[t]{4}{*}{$K$ - continentality value } & I & 0 & 7.7 & 100 & 0 & 0 & 0 \\
\hline & II & 0 & 0 & 100 & 7.1 & 0 & 0 \\
\hline & III & 0 & 0 & 94.7 & 10.5 & 0 & 0 \\
\hline & IV & 0 & 4.3 & 95.6 & 4.3 & 0 & 0 \\
\hline \multirow[t]{4}{*}{ W - soil moisture value } & I & 0 & 3.8 & 3.8 & 50 & 92.3 & 7.7 \\
\hline & II & 0 & 0 & 21.4 & 50 & 78.6 & 14.3 \\
\hline & III & 0 & 0 & 5.3 & 36.8 & 89.5 & 15.8 \\
\hline & IV & 0 & 0 & 8.7 & 47.8 & 82.6 & 13.0 \\
\hline \multirow[t]{4}{*}{ TR - trophy value } & I & 7.7 & 23.1 & 69.2 & 53.8 & 0 & 0 \\
\hline & II & 0 & 14.3 & 92.8 & 57.1 & 0 & 0 \\
\hline & III & 10.5 & 21.1 & 84.2 & 63.2 & 0 & 0 \\
\hline & IV & 8.7 & 26.0 & 73.9 & 47.8 & 0 & 0 \\
\hline \multirow[t]{4}{*}{$R$ - soil (water) acidity ( $\mathrm{pH}$ ) value } & $\mathbf{I}$ & 7.7 & 19.2 & 42.3 & 65.4 & 15.4 & 0 \\
\hline & II & 0 & 7.1 & 35.7 & 71.4 & 21.4 & 0 \\
\hline & III & 10.5 & 26.3 & 42.1 & 68.4 & 15.8 & 0 \\
\hline & IV & 13.0 & 17.4 & 39.1 & 69.6 & 8.7 & 0 \\
\hline \multirow[t]{4}{*}{$\mathrm{H}$ - organic matter content value } & $\mathbf{I}$ & 0 & 19.2 & 100 & 0 & 0 & 0 \\
\hline & II & 14.3 & 35.7 & 78.6 & 0 & 0 & 0 \\
\hline & III & 10.5 & 21.1 & 89.4 & 0 & 0 & 0 \\
\hline & IV & 7.7 & 26.9 & 80.8 & 0 & 0 & 0 \\
\hline
\end{tabular}

Table 4

Values of the selected abiotic environmental factors in the plots on the peat-bog near Lake Bikcze.

\begin{tabular}{lcccc}
\hline Plots & I & II & III & IV \\
\hline Level of ground water $(\mathbf{c m})$ & 4 & 1 & 10 & $0-5$ \\
Water acidity $(\mathbf{p H})$ & 3.54 & 4.25 & 4.89 & 5.45 \\
Water electrolytic conductivity $\left(\boldsymbol{\mu S} \times \mathbf{c m}^{-1}\right)$ & 74.2 & 433 & 144 & 162 \\
\hline
\end{tabular}




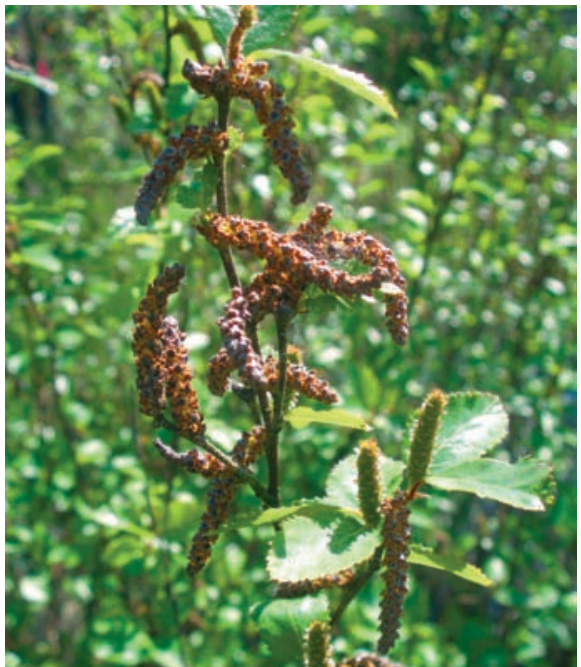

Fig. 1. Betula humilis blooming individual on the peat bog near Lake Bikcze.

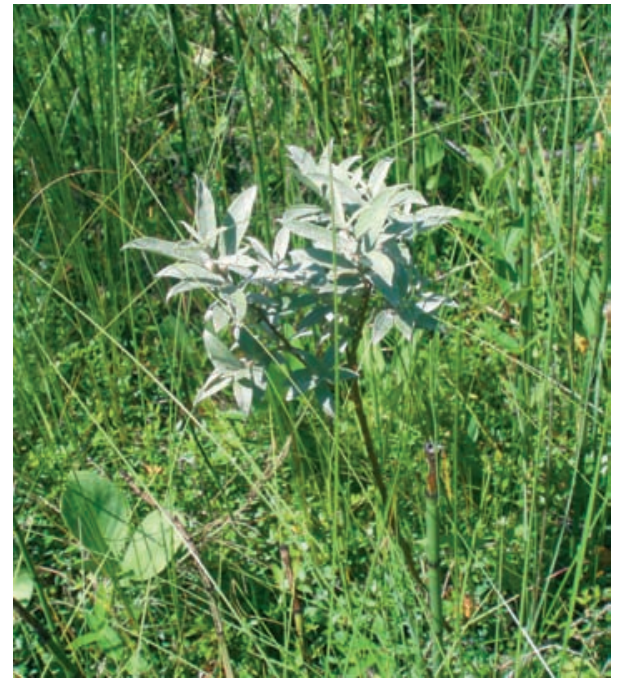

Fig. 2. Salix lapponum in studied area.

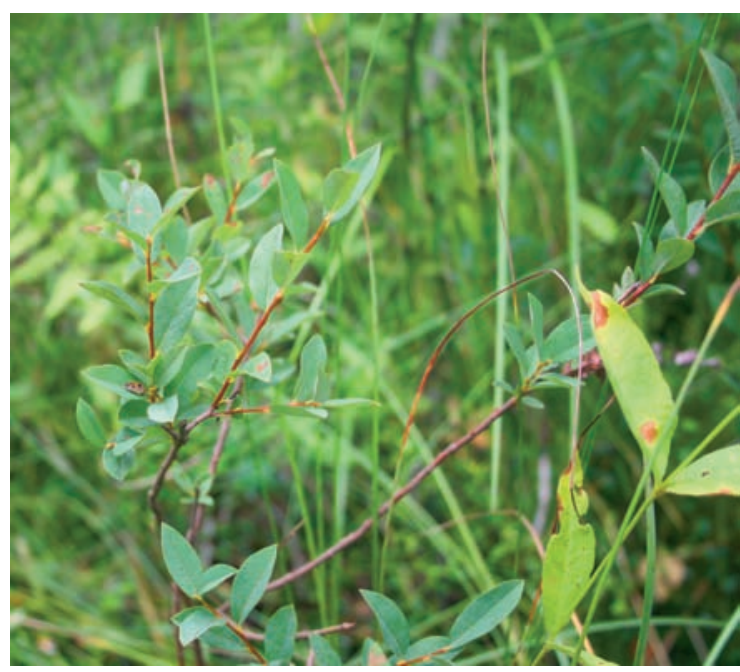

Fig. 3. Salix myrtilloides specimen in studied area on the peat bog.

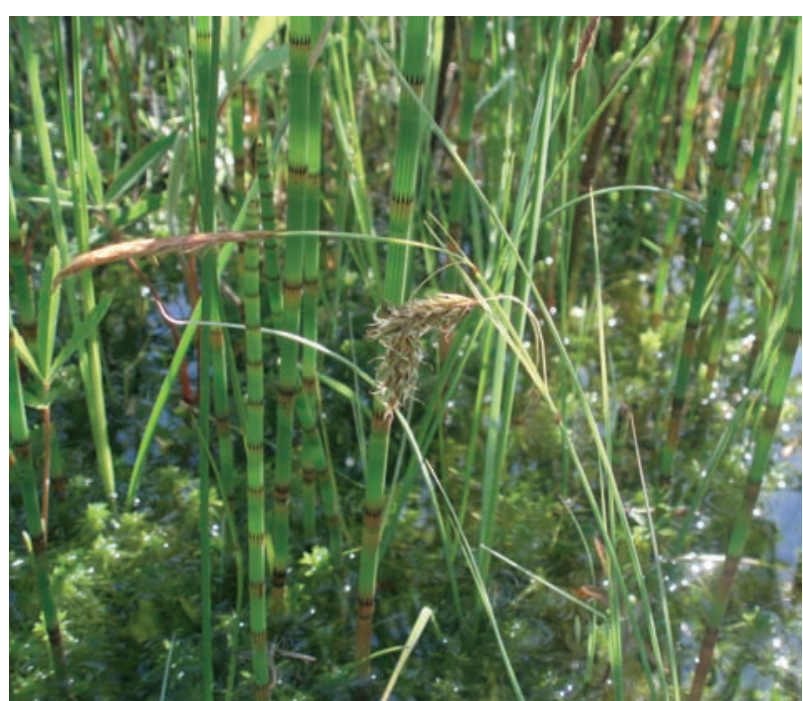

Fig. 4. Fructification of Carex limosa.

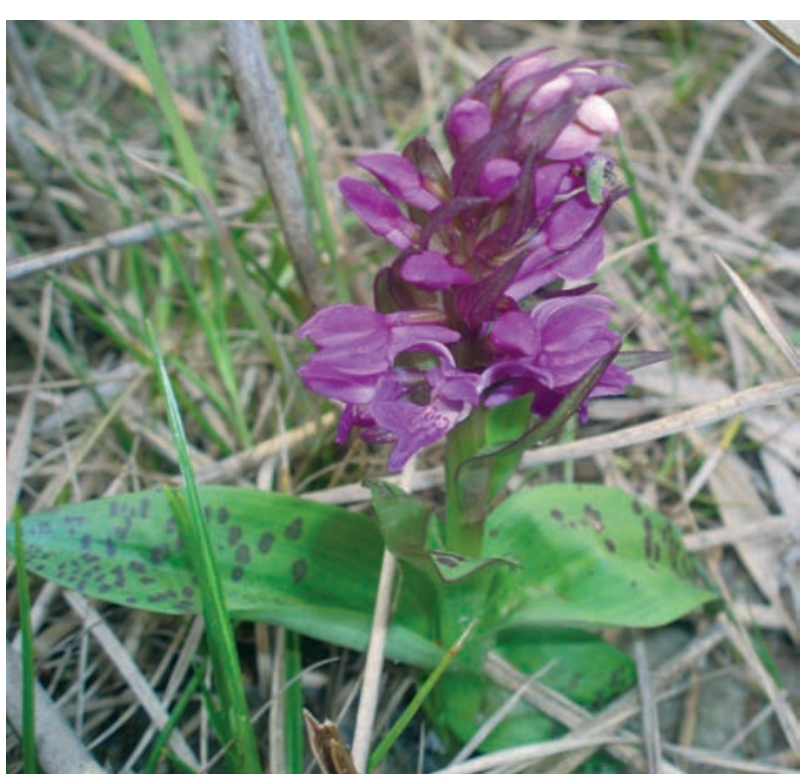

Fig. 5. Dactylorhiza incarnata on the peat bog near Lake Bikcze. 


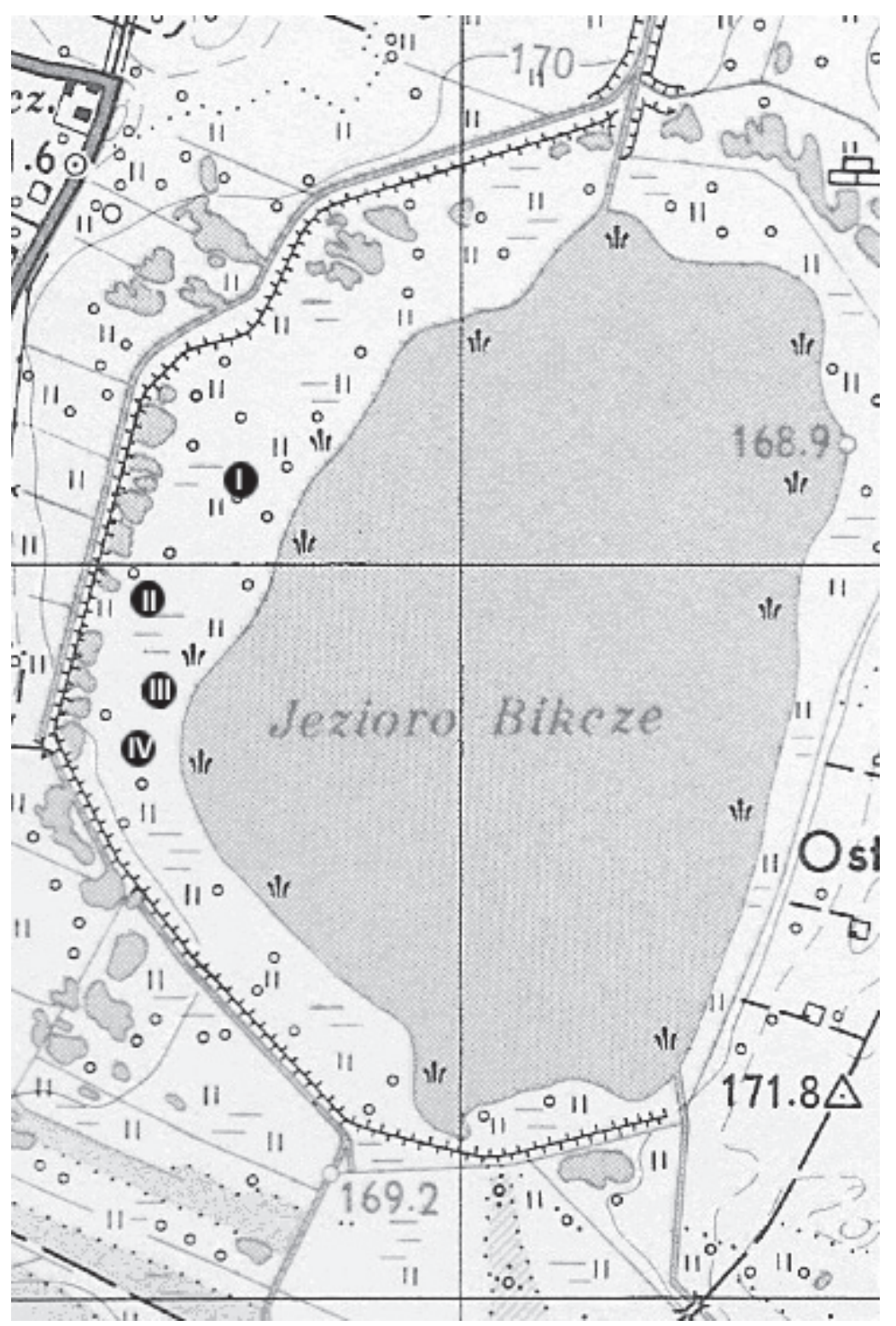

Fig. 6. Location of plots (I - IV) on the peat-bog near Lake Bikcze.

The largest plot (IV) was located in the central part of the peat bog. The phytocoenosis occurring there was abundant in unique boreal flora species. In the shrub layer, the occurrence of 5 Betula humilis shrubs and 15 Salix lapponum individuals was noted. The occurrence of a small population of Drosera rotundifolia (16 individuals) was also found, as well as over a dozen individuals of Carex limosa and Menyanthes trifoliata in quite great numbers. In total, the presence of 26 plant taxa was found in the study area. Study area IV was well insolated. The water level was different in various parts of the study area (from 0 to $5 \mathrm{~cm}$ ), and the $\mathrm{pH}$ was the highest of the reactions noted during the investigations (Tab. 4).
An analysis of the flora made using ecological indicator values ( $\mathrm{Zarzycki}$ and Korzeniak, 2002) demonstrated that, in the phytocoenoses of all the plots, species neutral to continentality were predominant, characteristic for areas with moderately cool or warm climatic conditions, preferring moderate light in their stands. There was a predominance of plant species characteristic for wetlands, mesotrophic habitats with slightly acid or neutral reaction of the substrate, as well as of species encountered on soils rich in organic matter (Tab. 3). 


\section{DISCUSSION}

D. Fijałkowski wrote already in 1959 that relict species occurring rarely in the flora of ŁęczyńskoWłodawskie Lakeland had no chance to survive resisting human economic activity. He paid special attention to the need of protection of the plant relict of glacial tundra.

When analysing the results of floristic studies from the 50's of the 20th century relating to, inter alia, the environs of Lake Bikcze, references can be found on the occurrence of Salix lapponum, S. myrtilloides, Betula humilis or Carex limosa there (F i j a łk ow s k i, 1958; 1958a; 1959). The confirmation of the occurrence of the abovementioned species in the area of investigation in 2007 may be evidence of the fact the conditions prevailing in the peat bog promote the development of their populations, in spite of the changes which have taken place in the environment over a period of 50 years.

According to Zarzycki and Korzeniak (2002), Salix lapponum, Betula humilis, Drosera rotundifolia and Carex limosa are species threatened with extinction, whereas Salix myrtilloides and Drosera intermedia are at particular risk of extinction. Among the protected species encountered in the studied peat bog, as many as 7 species belong to a group with respect to which a large decline in the number of stands has been noted over the last decades, whereas Drosera intermedia, S. lapponum and S. myrtilloides are species with a small number of stands in our country (Zarzycki and Korzeniak, 2002).

The peat bog on Lake Bikcze abounds in rare and currently legally protected plant species. Populations of the abovementioned species, as follows from the observations carried out in 2007, were numerous and habitat conditions in the investigated stands suited their requirements. Both the investigation of abiotic factors, conducted in situ, and the analysis of the species composition of the flora, in terms of habitat preferences of particular groups of taxa, have demonstrated that the described legally protected plant species find suitable conditions for their growth and development in the studied peat bog.

The results of the pilot field study, carried out in 2007, also show that the vegetation in the peat bog on Lake Bikcze is very diversified, also in syntaxonomic terms. It is confirmed by earlier phytosociological investigations conducted in the peat bog ( $\mathrm{z} \mathrm{d} \mathrm{e} \mathrm{b} \mathrm{s} \mathrm{k} \mathrm{i} \mathrm{et}$ al. 1996; L or e n s et al. 1998). The quickly advancing ecological succession, already observed earlier, which is primarily manifested in the encroachment of expansive species on the peat bog area (Salix cinerea, Phragmites australis, Betula pendula), affects changes in habitat conditions by shading and drying up the area. In the future, these phenomena may have a nega- tive impact on the development of populations of the rare plants which are usually sensitive to any changes taking place in their habitats.

A continuation of the studies on the flora and habitat conditions existing in the peat bog on Lake Bikcze would allow us determine the proper direction and principles of active protection of this area, which seems to be necessary. It is particularly important due to exceptional natural values which characterize the said peat bog.

\section{REFERENCES}

Baryła R., Fijałkowski D. 1995. Roślinność naczyniowa jezior i torfowisk w rejonie Poleskiego Parku Narodowego i jego otuliny. / Vascular flora of lakes and peat bogs in the area of Poleski National Park and its protection zone. [In:] Radwan S. (ed.). 1995. Ochrona ekosystemów wodnych w Poleskim Parku Narodowym i jego otulinie. / Protection of aquatic ecosystems in Poleski National Park and its protection zone. Wyd. TWWP, Lublin.

Bolek I. 2005. Szata roślinna północnej części torfowiska nad jeziorem Bikcze (Pojezierze Łęczyńsko-Włodawskie). / The vegetation cover of the northern part of the peat bog on Lake Bikcze (Łęczyńsko-Włodawskie Lakeland). Praca magisterska - maszynopis w Katedrze Ekologii Ogólnej AR w Lublinie. Lublin. / Master's thesis - manuscript at Department of General Ecology, University of Life Sciences in Lublin.

Burzak A. 2005. Szata roślinna południowej części torfowiska nad jeziorem Bikcze (Pojezierze Łęczyńsko-Włodawskie. / The vegetation cover of the southern part of the peat bog on Lake Bikcze (Łęczyńsko-Włodawskie Lakeland). Praca magisterska - maszynopis w Katedrze Ekologii Ogólnej AR w Lublinie. Lublin. / Master's thesis - manuscript at Department of General Ecology, University of Life Sciences, Lublin.

Fijałkowski D. 1958. Badania nad rozmieszczeniem i ekologią wierzby lapońskiej (Salix lapponum L.) na Pojezierzu Łęczyńsko-Włodawskim. / Studies on the distribution and ecology of downy willow (Salix lapponum) in Łęczyńsko-Włodawskie Lakeland. Fragm. Florist. Geobot. 3 (2), 89-103.

Fijałkowski D. 1958a. Obserwacje nad ekologią i nad rozmieszczeniem wierzby borówkolistnej (Salix myrtilloides L.) na Pojezierzu Łęczyńsko-Włodawskim. / Observations on the ecology and distribution of Salix myrtilloides in Łęczyńsko-Włodawskie Lakeland. Acta Soc. Bot. Pol. XXVII (4): 605-612.

Fijałkowski D. 1959. Szata roślinna jezior Łęczyńsko-Włodawskich i przylegających do nich torfowisk. / The vegetation cover of lakes in the Łęczna and Włodawa area and of peat bogs adjacent to these lakes. Ann. UMCS, Sec. B, XIV: 131-203.

Izdebski K., Grądziel T., Lorens B., Popiołek Z. 1996. Procesy zachodzące w środowiskach roślinnych ekotonów woda-ląd na obszarze objętym programem 
renaturyzacji. / Processes taking place in plant environments of water-land ecotones in the area covered by the renaturalisation programme. [In:] Chmielewski T.J. (ed.) Renaturyzacja ekosystemów wodno - torfowiskowych na Pojezierzu Łęczyńsko-Włodawskim. / Renaturalisation of aquatic-bog ecosystems in Łęczyńsko-Włodawskie Lakeland. Wyd. UMCS, Lublin.

Lorens B., Grądziel T., Sugier P. 1998. Zmiany roślinności w ekotonie woda-ląd jeziora Bikcze w latach 1993 1998. / Changes in vegetation in the water-land ecotone of Lake Bikcze in the years 1993-1998. [In:] Radwan S. (ed.): Ekotony słodkowodne - struktura - rodzaje - funkcjonowanie. / Inland water ecotones - Structure - Types - Function. Wyd. UMCS, Lublin.

Matuszkiewicz W. 2005. Przewodnik do oznaczania zbiorowisk roślinnych Polski. / Guide for identification of Poland's plant communities. Wyd. PWN, Warszawa.

Mirek Z., Piękoś-Mirkowa H., Zając A. i M. 2002. Flowering plants and pteriodohytes of Poland. A checklist Wyd. Instytut Botaniki PAN, Kraków.

Pogorzelec M. 2004. Wierzba lapońska (Salix lapponum L.) na Polesiu Lubelskim. / Salix lapponum in Polesie Lubelskie District. Rozprawa doktorska - maszynopis w Katedrze Ekologii Ogólnej UP, Lublin. / Doctoral thesis - manuscript at Department of General Ecology, University of Life Sciences, Lublin.

Radwan S. (ed.), 2003. Przyrodnicze podstawy ochrony i odnowy ekosystemów wodno torfowiskowych w obszarze funkcjonalnym Poleskiego Parku Narodowego na tle antropogenicznych przekształceń środowiska przyrodniczego - Rozprawy i monografie. / The environmental basis for protection and restoration of aquatic-bog ecosystems within the functional area of Poleski National Park against the background of anthropogenic transformations of the natural environment - Dissertations and monographs. Acta Agroph. 91: 7-237.

Rozporządzenie Ministra Środowiska z dnia 9 lipca 2004 r. w sprawie gatunków dziko występujących roślin objętych ochrona. / Regulation of the Minister of Environment of 9 July 2004 on protected wild plants Dz. U. $\mathrm{Nr} 168$.

Rutkowski L. 1998. Klucz do oznaczania roślin naczyniowych Polski niżowej. / Key for identification of vascular plants in lowland Poland. Wyd. Nauk. PWN, Warszawa.
Wilgat T. 1953. Jeziora Łęczyńsko-Włodawskie. / Lakes of the Łęczna and Włodawa area. Ann. UMCS, Sect. B, 8. Lublin.

Wojciechowski I. 1976. Wpływ zlewni na eutrofizację a-mezotroficznego jeziora Piaseczna i na deeutrofizacje stawowego jeziora Bikcze. / Influence of the drainage basin on eutrophication of the amesotrophic Lake Piaseczno and on de-eutrophication of the pond lake Bikcze. Acta Hydrobiol., Kraków

Wysocki C., Sikorski P. 2002. Fitosocjologia stosowana. Wyd. SGGW, Warszawa.

Zarzycki K., Korzeniak U. (ed.). 2002. Ecological indicator values of vascular plants of Poland. Wyd. Instytut Botaniki PAN, Kraków.

\section{Występowanie gatunków roślin rzadkich i chronionych na torfowisku nad jeziorem Bikcze (Pojezierze Lęczyńsko-Włodawskie)}

\section{Streszczenie}

Praca przedstawia wyniki terenowych badań pilotażowych prowadzonych w lipcu 2007 roku, mających na celu waloryzację florystyczną terenu torfowiska sąsiadującego z zachodnim brzegiem jeziora Bikcze (Pojezierze Łęczyńsko-Włodawskie). Głównym celem badań było potwierdzenie występowania na tym terenie populacji rzadkich i objętych ochroną prawną gatunków roślin oraz wstępne rozpoznanie warunków siedliskowych w ich stanowiskach.

Potwierdzono występowanie na badanym torfowisku populacji gatunków roślin objętych ochroną ścisłą: Betula humilis, Salix lapponum, Salix myrtilloides, Carex limosa, Drosera intermedia, Drosera rotundifolia, Dactylorhiza incarnata oraz ochroną częściową Menyanthes trifoliata.

Zarówno badania czynników abiotycznych, prowadzone in situ, jak i analiza składu gatunkowego flory pod kątem preferencji siedliskowych poszczególnych grup taksonów wykazały, że opisane gatunki roślin rzadkich znajdują dogodne warunki do wzrostu i rozwoju na badanym torfowisku. 